\title{
COMPUTERIZATION OF THE ARTICLE 9 FILING SYSTEM: THOUGHTS ON BUILDING THE ELECTRONIC HIGHWAY*
}

\author{
LyNN M. LoPUCKI**
}

\section{INTRODUCTION}

Scholars are in disagreement as to what, if anything,' the article 9 filing system is supposed to accomplish. ${ }^{2}$ But there seems to be universal agreement on one point. An important purpose of the system is to communicate the existence of filed financing statements to those who search the records. If a filing was made, a searcher should be able to find it. ${ }^{3}$

Copyright $\odot 1992$ by Law and Contemporary Problems

* The highway metaphor is taken from Peter Robinson, Karl P. Sauvent \& Vishwas P. Govitrikar, eds, Electronic Highways for World Trade: Issues in Telecommunications and Data Services (Westview Press, 1989).

** Professor of Law, University of Wisconsin.

Professor Peter A. Alces of the Marshall-Wythe School of Law of the College of William and Mary and Professor Robert M. Lloyd of the University of Tennessee College of Law generously provided access to data from the Survey of the UCC Article Nine Filing System conducted by the American Bar Association's Filing System Task Force under their direction. The members of the Task Force who contributed to the report of the survey are Mary Atkinson, John Berchild, Michael Brandt, Barbara Clark, Marvin Gillock, Bruce Jacobi, Robert Lloyd, Ann Lousin, Alemante Selassie, and Jan Whitehead Swift. Professor Charles W. Mooney, Jr., of the University of Pennsylvania Law School was both a sounding board and a source of ideas. The author is indebted to Peter Alces, Kathryn Heidt, Gerald Thain, and Elizabeth Warren for their comments on earlier drafts of this article.

1. In the initial debates over the adoption of article 9, some argued that the costs of a filing system would exceed its benefits. Skepticism about worth of a filing system continues. See, for example, James J. White \& Robert S. Summers, Uniform Commercial Code $\$ 22-7$ at $992 \mathrm{n} 2$ (West, 1988); Alan Schwartz, $A$ Theory of Loan Priorities, $18 \mathrm{~J}$ Legal Studies 209 (1989).

2. See Douglas G. Baird \& Thomas H. Jackson, Possession and Ownership: An Examination of the Scope of Article 9, 35 Stan L Rev 175 (1983); Charles W. Mooney, The Mystery and Myth of "Ostensible Ownership" and Article 9 Filing: A Critique of Proposals to Extend Filing Requirements to Leases, 39 Ala L Rev 683,749 (1988) (identifying a broad range of purposes served by the filing system and criticizing Baird and Jackson's emphasis on ostensible ownership); Schwartz, $18 \mathrm{~J}$ Legal Studies 209 (cited in note 1); Douglas G. Baird \& Thomas H. Jackson, Information, Uncertainty, and the Transfer of Property, 13 J Legal Studies 299, 312 (1984); Douglas G. Baird, Notice Filing and the Problem of Ostensible Ownership, $12 \mathrm{~J}$ Legal Studies 53 (1983).

3. Grant Gilmore, Security Interests in Personal Property 463 (Little, Brown, 1965) ("It is quite probably true that the newer filing systems were improvements on the older ones in the sense that they were better designed to give actual notice to creditors."); White \& Summers, Uniform Commercial Code $\$ 22-7$ at 992 (cited in note 1) ("Code drafters believed that, to have the rights of a perfected secured creditor, one should in the normal course of events undertake some action, either filing or possession, which would put a diligent searcher on notice of the secured party's claim. The drafters also wished to increase the certainty that ... a good faith search would reveal the presence of the secured creditor's claim."); Baird \& Jackson, 35 Stan L Rev at 175 (cited in note 2) ("IThe requirement that a secured party take possession or file] enables a creditor who wants to lend money on a secured basis to assume that, if the property in question is in the debtor's possession and if no other creditors have filed a financing statement, his claim to that property can have priority over 
Scholars have been increasingly skeptical of the system's ability to accomplish even this limited purpose. A recent study by the American Bar Association's Article 9 Filing System Task Force (the ABA Task Force) largely confirms their skepticism. ${ }^{4}$ As the article 9 filing system is currently conceived and implemented, (1) it is impractical for a secured creditor to do everything necessary to make and maintain an effective filing, (2) many kinds of filings are effective even though they are, as a practical matter, impossible for searchers to discover, and (3) the processes for both filing and searching are unreasonably complex and error-prone. Part I of this article provides a quick overview of the misdesign and malfunctioning of the filing system. Part II explores the possibility that further computerization can make the system functional. It concludes that currently available computer technology is capable of overcoming most of the deficiencies identified in Part I and creating a medium that communicates the contents of filed financing statements quickly, accurately, and efficiently. Part III predicts that if such improvements in the filing and search capacities of the article 9 filing system are made, they will highlight other basic inadequacies in system design. Theorists credit the existing system as showing whether specific items of collateral are or are not encumbered. In fact, it performs only a small part of that task. To accomplish the rest will require more than computerization. It will require, at minimum, the addition of new types of data.

\section{The Article 9 Filing System: Crumbling Infrastructure of THE INFORMATION AGE}

Most of the failures of the article 9 filing system have been noted and discussed at length in cases or commentary. It is their number, scope, and cumulative effect on the system's ability to achieve its purpose that are addressed here. For that reason, each failure is dealt with briefly in the following lists.

those of other existing and future creditors."); Baird \& Jackson, $13 \mathrm{~J}$ Legal Studies at 312 (cited in note 2) ("One is obliged to stake one's claim in the filing system so that future parties will be able to find it."); Baird, $12 \mathrm{~J}$ Legal Studies at 63 (cited in note 2) ("[A] creditor can lend money to a debtor with confidence because he knows (by looking at the files) that no other existing creditor can claim an interest in the property superior to his own."); Schwartz, $18 \mathrm{~J}$ Legal Studies at 209 (cited in note 1) (treating the filing system and private financial statements as competing methods of "disclosing" debt); but see Mooney, 39 Ala L Rev at 749 (cited in note 2) (recognizing that many kinds of claims cannot be discovered merely by examining the collateral and the public record).

4. See Peter A. Alces, Survey of the U.C.C. Article 9 Filing System (American Bar Association Filing System Task Force, 1991) ("Alces Survey"); Peter A. Alces \& Robert M. Lloyd, Report of the Uniform Commercial Code Article 9 Filing System Task Force to the Permanent Editorial Board's Article 9 Study Committee (Permanent Editorial Board for the Uniform Commercial Code, 1991) ("Alces and Lloyd Report"). The report is an internal work product of an advisory committee to the article 9 study committee of the Permanent Editorial Board for the Uniform Commercial Code. It does not necessarily reflect the position of the Study Committee, the Permanent Editorial Board, or its sponsors (the American Law Institute and the National Conference of Commissioners on Uniform State Laws). 
A. Many Kinds of Filings Remain Effective Even Though It Is Impossible to Discover Them in a Search

The following are some of the most important categories of filings that may not be discoverable, even through a reasonably diligent search:

(1) Filings Made Against the Debtor's Predecessor in Title. For example, D1 owns business equipment. D1 gives a security interest in the equipment to S1. S1 perfects the interest by filing. The financing statement is properly indexed in the name of D1. D1 sells the equipment to D2 subject to the security interest, and D2 takes possession. D2 then applies for a loan from S2 (without mentioning $\mathrm{D} 1$ or S1) and offers S2 a security interest in the equipment. S2's search for filings under the name D2 will not turn up S1's security interest. Nevertheless, $\mathrm{S} 1$ will have priority over S2.5

(2) Filings That Are Indexed or Searched Incorrectly. If S1 presents a sufficient financing statement to the filing officer and tenders the filing fee, the financing statement will be effective. This is true even if the financing statement is neither filed nor indexed and therefore could not be found by a later searcher. ${ }^{6}$ Similarly, if Sl's financing statement were filed properly but the filing officer mistakenly omitted it from the search certificate issued to $\mathrm{S} 2$, it would remain effective against $\mathrm{S} 2.7$

(3) Filings Not Yet Indexed at the Time of the Search. Financing statements are effective as of the date and time of filing. However, in many filing offices the statements cannot be discovered until they are entered or even indexed. Entry and indexing may take anywhere from about twenty-four hours to three or four weeks. ${ }^{8}$

(4) Filings Made Before a Change in the Debtor's Name. For example, S1 perfects a security interest in business equipment owed by $D$. $D$ then changes its name to "X." Sl's filing remains effective. ${ }^{9}$ When $\mathrm{X}$ offers the equipment to $\mathrm{S} 2$ as collateral for a loan, it may be difficult or impossible for $\mathrm{S} 2$ to discover $\mathrm{S} 1$ 's filing. ${ }^{10}$

5. UCC $\S 9-402(7)$. Comment 8 explains: "Thus, any person searching the condition of the ownership of a debtor must make inquiry as to the debtor's source of title, and must search in the name of a former owner if circumstances seem to require it." This failure is discussed at length in Jay Lawrence Westbrook, Glitch: Section 9-402(7) and the U.C.C. Revision Process, 53 Geo Wash L Rev 408 (1984).

6. See UCC $\$ 9-403(1)$.

7. In some states, $\mathbf{S} 2$ will have a cause of action against the filing officer for any damages $\mathbf{S} 2$ suffers. In other states, the action will be barred. See, for example, Kan Stat Ann $\$$ 84-9-407(3) (Vernon Supp 1986) (state and filing officers immune except for willful misconduct).

8. Alces \& Lloyd Report at App 2 (cited in note 4).

9. UCC $\$ 9-402(7)$. This failure is discussed at length in Westbrook, 53 Geo Wash L Rev 408 (cited in note 5 ).

10. To discover the filing, $\mathrm{S} 2$ must first discover the former name. If $\mathrm{X}$ is a corporation, $\mathrm{S} 2$ can discover the change by searching the corporate records in the state of incorporation. If $\mathrm{X}$ is a natural person, the change of name may be in the court records of nearly any court of general jurisdiction in the United States, in the court records of a foreign country, or there may be no court record at all. See notes 21-22 and accompanying text. 
(5) Filings Made in Another Jurisdiction Before the Collateral Was Moved. For example, $\mathrm{Sl}$ perfects a security interest in inventory while the inventory is in State $A$. The debtor then moves the inventory to State B. Less than four months after the move, the debtor offers it to S2 as collateral. Although S2 may have no practical means of knowing that the collateral was moved or discovering Sl's filing in State A, S1's security interest remains perfected. " I

(6) Filings Made Against Mobile Goods Before the Debtor Moved. For example, $\mathrm{S} 1$ properly perfects a security interest in mobile goods by filing in State A where D, a corporation, has its chief executive office. ${ }^{12} \mathrm{D}$ then moves its chief executive office to State B. Less than four months after the move, D offers the mobile goods to S2 as collateral. Although $\mathbf{S} 2$ may have no practical means of discovering Sl's filing in State A, Sl's security interest remains perfected. ${ }^{13}$

(7) Filings Made in a County Before the Goods or Debtor Are Moved to Another County. For example, while $\mathrm{D}$ resides in County A, S1 perfects a security interest in D's farming equipment by filing a financing statement in the records of County $A$. D then moves to County B and offers the farming equipment to $\mathrm{S} 2$ as collateral. S1's financing statement remains effective against $S 2^{14}$ even though there may be no way for $S 2$ to know that $D$ resided in County $A$ or that the financing statement is on record there.

(8) Filings Made in County Records Before the Nature or Use of the Goods Was Changed. For example, S1 perfects a security interest in D's farming equipment and consumer goods by filing in the county records. Later, D converts these goods to use as business equipment and offers them to $S 2$ as collateral. $S 1$ 's financing statement remains effective against $S 2^{15}$ even though $S 2$ might have no reason to suspect that the goods had ever been in a different use or that they could be encumbered by a county filing.

(9) Filings Against Consumer Goods. For example, Sears sells a washer and dryer to the Smiths. Sears retains a security interest in the goods and perfects it by filing in the county where the Smiths reside. The Smiths sell the washer and dryer to the Jones at a garage sale without revealing the existence of Sears's interest. Sears's filing is effective against the Jones, even though the Jones have no realistic opportunity to search. ${ }^{16}$ In evaluating the importance of this exception to the filing requirement, it is important to realize that whether goods are consumer goods depends not on their nature or

11. UCC \& 9-103(1)(d).

12. When the collateral is mobile goods, the proper place to file ordinarily is in the state where the debtor has its chief executive offices. See id $\S 9-103(3)$.

13. Id $\$ 9-103(3)(\mathrm{e})$.

14. Id \$ 9-401(3).

15. Id.

16. Id $\$ 9-307(2)$. 
value, ${ }^{17}$ but on the purpose for which they were bought or used.

Virtually any goods may be (or have been) consumer goods.

Finally, some judges have bizarre ideas about how a reasonably prudent searcher conducts its search. Some assume that searchers will dally in the system long enough to notice filings against incorrect names. ${ }^{18}$ Others go even farther and assume that searches will be conducted against incorrect names, such as trade names, ${ }^{19}$ as well as correct names. Cases such as these expand the types of financing statements that will be effective even though they cannot reasonably be found in a search.

\section{B. Even a Diligent Filer May Be Unable to Achieve or Maintain an Effective Filing}

Below are some situations in which even a reasonably diligent filer may be unable to achieve or maintain an effective filing:

(1) Debtor Is Not the Owner of the Collateral. A financing statement is effective only if it correctly names the owner of the collateral. Yet, there is no authoritative source for such ownership information. Filers must either accept D's representation of ownership or conduct an off-record investigation that might include examination of invoices, bills of sale, canceled checks, and financial statements. Recall that the filing system itself exists because we do not trust this kind of investigation to discover security interests.

(2) Debtor Gives Filer An Incorrect Form of Name. Misspelling or using an incorrect version of D's individual or corporate name can be enough to render a filing ineffective. ${ }^{20}$ The correct name in which to file against an individual debtor is the name by which $\mathrm{D}$ is generally known. ${ }^{21}$ There is no public record or authoritative source from which that name can be precisely determined. It can also be changed

17. By nonuniform amendment, a few states limit the consumer goods exception to consumer goods of less than a particular dollar value, see, for example, Wis Stat $\$ 409.302(1)$ (d) (1989-90) ( $\$ 500$ limit), rendering this flaw in the system relatively harmless in situations governed by the laws of those states.

18. See, for example, In re Alexander, 39 Bankr 110, 111 (Bankr ND 1984) ("[T] he court believes it reasonable that a creditor interested in the property of John and Larry Alexander within the largely rural county of Benson County, North Dakota, would examine all financing statements filed under the name Alexander.").

19. Even though the Code "contemplates filing only in the individual name, not in a trade name," see comment 7 to UCC $\$ 9-402$, some courts consider at least some filings under trade names to be effective. See, for example, Brushwood v Citizens Bank of Perry (In re Glasco, Inc.), 642 F2d 793 (5th Cir 1981) (filing under trade name held effective against debtor's trustee in bankruptcy because the company did business only in the trade name). See generally Julianna J. Zekan, The Name Game-Playing To Win Under $\$ 9-402$ of the Uniform Commercial Code, 19 Hofstra L Rev 365 (1990).

20. In re Tyler, 23 Bankr 806 (Bankr SD Fla 1982).

21. "In the absence of any restrictive statute, it is the common-law right of a person to change his name, or he may by general usage or habit acquire a name notwithstanding it differs from the one given him in infancy. A man's name for all practical and legal purposes is the name by which he is known and called in the community where he lives and is best known ... . He may be as well known by one name as by another, and in such case the use of either is for most purposes sufficient." Hauser v Callaway, 36 F2d 667, 669-70 (8th Cir 1929) (citations omitted). See In re Gustafson, 14 UCC Rep Serv 231, 236 (Bankr WD Okla 1973) (A financing statement containing the debtor's "adopted and 
formally through divorce or other legal proceeding. It can be changed informally, as when the potential debtor begins using first initial and middle name on documents, or when a nickname sticks. In fact, to say that it changes may be to assume falsely that it was a particular thing to begin with. For many, if not most, Americans, that is not true. For example, John Lawrence Smith may be referred to as John L. Smith, J. L. Smith, J. Lawrence Smith, or Jack Smith. To assert that one of these is his "correct" or "legal" name is to engage in fiction. Yet, many courts expect the filer to discover and file in the "correct" name. ${ }^{22}$ Few Uniform Commercial Code ("UCC") search systems provide help with this problem. Instead, they operate on the assumption that the searcher will order a separate search for each possible variation of D's name. ${ }^{23}$

Corporate names are less problematic because there is an authoritative source in public records. But use of that source constitutes a second search, which has its own uncertainties. ${ }^{24}$

(3) Debtor Changes Its Name. For example, S finances D's inventory under an arrangement that includes a security interest in afteracquired property. After the arrangement is in place, D changes its name. UCC section 9-402(7) provides that S's financing statement will be ineffective with regard to inventory acquired more than four months after the change. But how is $S$ supposed to discover the change? S's choice would seem to be to monitor the corporate records of the state at intervals no greater than four months or to rely on $\mathrm{D}$ to bring the change to its attention.

(4) Debtor Removes Collateral from the State. For example, S takes a security interest in "ordinary goods," such as equipment or inventory, and perfects by filing in State A where the goods are located. Later, D removes the goods to state B. Unless $\mathrm{S}$ discovers the move and files in State B, S's perfection will lapse four months after the move. ${ }^{25}$ S's choice would seem to be to monitor the collateral at intervals no greater than four months to determine if it has been moved or to rely on $\mathrm{D}$ to bring the change to its attention.

publicly accepted name" met the Code's notice requirement even though the name was not the debtor's "true" name.).

22. For example, a filing against "James M. Hurt" was held ineffective because the debtor was generally known as "Malcolm Hurt." United States $v$ Smith, 22 UCC Rep Serv 502 (ND Miss 1977).

23. For example, in the New York system, the search logic requires "exact debtor's name as given in search request. Searchers must provide different variations of name, if they desire." Alces Survey, question 7 on New York questionnaire (cited in note 4).

24. For example, assume that the correct name of the corporation is "Variform, Inc." To prevent the searcher from discovering financing statements already filed against its property, Variform represents that its trade name, "Variflex, Inc.," is its corporate name. If there is in fact a corporation registered under the name "Variflex, Inc.," even a search of the corporate records may not expose the misrepresentation. In such a situation, the searcher must rely on information such as address and names of officers and directors to distinguish the corporations.

25. UCC § 9-103(1)(d). 
Monitoring will be impractical for many kinds of collateral, such as the inventory of a drug store or an auto parts store. ${ }^{26}$

(5) Debtor Moves Chief Executive Office from the State. For example, S takes a security interest in "mobile goods," such as shipping containers. ${ }^{27} \mathrm{~S}$ properly perfects by filing in State $\mathrm{A}$, the location of D's chief executive office. Later $D$ moves its chief executive office to State B. Unless $S$ discovers the move and files in State B, S's perfection will lapse four months after the move. ${ }^{28} \mathrm{~S}$ 's choice would seem to be to monitor the location of D's chief executive office at intervals no greater than four months or to rely on $\mathrm{D}$ to bring the change to its attention. The chief executive offices of companies in financial difficulty frequently are moved. ${ }^{29}$ There may be virtually no observable manifestation of the move. For example, it may be something as subtle as a change in the amount of time the chief executive officer spends in New York. ${ }^{30}$

(6) Debtor Obtains a Certificate of Title for Previously Uncertificated Goods. D purchases two mobile homes that are not covered by certificates of title. S makes a purchase money loan against each of the mobile homes. One of the mobile homes is consumer goods; as to it, $S$ is perfected without filing. The other is equipment; as to it, $S$ properly perfects by filing in the article 9 filing system. Later, D obtains certificates of title for both mobile homes. Because $D$ does not mention them to the certificate issuer, S's security interests are not noted on either certificate. They have become unperfected. ${ }^{31}$

(7) Debtor Affixes Collateral to Real Estate. S properly perfects a security interest in equipment by filing. $D$ affixes the equipment to previously mortgaged real estate owned by $D$. The equipment is not "readily removable." $32 \mathrm{~S}$ has lost its priority to the real estate mortgagee. ${ }^{33}$

\section{The Processes for Filing and Searching Are Unreasonably Complex}

1. Differences in Filing Requirements. The more than 4,200 filing offices in the United States enforce a variety of filing requirements and procedures. For example, the fee for filing a financing statement differs from state to state and

26. Most businesses will have records showing what is in inventory at a particular location. But to check and rely on the debtor's records is little better than to rely on the debtor. If a debtor in the auto parts business opened a new store in state $B$ and moved a specialized portion of its inventory to that store without notifying $S$, it might be entirely impractical for $S$ to discover the move through visual inspection of the inventory in state $A$.

27. See id $\$ 9-103(3)$.

28. Id $\$ 9-103(3)(e)$.

29. Lynn M. LoPucki \& William C. Whitford, Venue Choice and Forum Shopping in the Bankruptcy Reorganization of Large, Publicly Held Companies, 1991 Wis L Rev 11 n24 (At least 35\% of the companies studied moved their headquarters to a different city at or about the time of the reorganization case.).

30. Id at note 60 (ambiguity as to the location of the corporate headquarters in the BaldwinUnited and Tacoma Boatbuilding cases).

31. UCC $\$ \$ 9-302(3), 9-103(2)$.

32. See id $\S 9-313(4)(c)$.

33. See id \$ 9-313(4). 
from county to county. Some states require that filings be on particular forms, but not all states use the same forms. A mistake in the amount of the fee or the form of the filing can result in rejection by the filing officer. The ABA Task Force reported that " $[i]$ most states, approximately 10 percent to 15 percent of the filings are rejected, although California reported rejecting 49 percent of filings offered on form UCC-2."34

Thus, unless the filer regularly deals with the particular filing office, the first step in filing is usually to phone the filing officer to ask for local fee and filing information. The necessity to tailor filings to the particular office precludes widespread filing except when large amounts of money are involved. The maxim that one should "file everywhere" is clearly not one that can be taken literally. ${ }^{35}$

2. Deceptive Rejection Policies. In some states, these rejections may come days after the filings were accepted over the counter. ${ }^{36}$ In the interim, another filer may establish priority or an applicable grace period may expire. ${ }^{37}$

3. Limited Search Access. Systems differ widely as to the manner in which searches can be conducted. In some offices, members of the public have direct access to the records or to a computer terminal from which a search can be conducted. If a search does not produce the expected results, the searcher can check for errors and try variations. But even though it is widely acknowledged that search quality is heavily dependent on the skill of the searcher, ${ }^{38}$ in many of the systems, searches can be conducted only by employees of the filing office. ${ }^{39}$

4. Delays in Filing and Searching. Filings are effective from the moment they are tendered to the filing officer. ${ }^{40}$ But there will be a delay of about twentyfour hours to as long as a month before the filing will be entered, indexed, and discoverable through a search. ${ }^{41}$ These stamped but unprocessed filings are generally referred to as the "basket." In most real estate recording

34. Alces and Lloyd Report at 16 (cited in note 4).

35. See note 63 .

36. Rejection may come as much as a week after the filing is accepted over the counter. Alces and Lloyd Report at 16 (cited in note 4).

37. See notes 108-10 and accompanying text.

38. For example, the Alces Survey reveals that “[i]n most states, however, human operators intervene to search for similar names, but few, if any, states have written procedures telling the operator exactly how to go about this. This means that search accuracy depends upon the skill, judgment and diligence of the individual operator." Alces and Lloyd Report at 20 (cited in note 4).

39. In recent years, many state filing officers have begun selling copies of their data bases to UCC service companies who then make them available to users "on-line." For regular users, on-line searching is more convenient than searching in the office of the Secretary of State, but it has two important shortcomings. First, the data base contains only the index entries for the financing statements; to obtain copies of the statements themselves, the searcher must order from the filing officer. Second, there is usually a delay of a few weeks between the time an item is entered to the filing officer's index and the time it is discoverable through the service company's data base. To close that gap would require an additional, later search in the official records.

40. UCC \$9-403(1).

41. Alces and Lloyd Report at app 2 (cited in note 4). 
systems, searchers have access to the basket. But in most article 9 filing systems, they do not. There is nothing the searcher can do except wait for the filing to be added to the system. "Expedited" searches are available in some states for an additional fee of about five to twenty-five dollars, ${ }^{42}$ but these may involve hours of delay and still not include the entire basket. ${ }^{43}$ Even if the delays in obtaining a complete search are short, they sharply limit the searcher's ability to experiment by varying the search.

5. Working Through the Index. In most states, only some of the information on the financing statement is entered to the computer. Other information, such as the description or type of collateral covered, is discoverable only from the face of the financing statement, which is kept on microfilm, microfiche, or paper. This means that most searches will have two phases. The first is a computer search of the index. It identifies the financing statements that may be relevant to the search. In the second phase, those financing statements are retrieved and examined or copied. In most systems, the second phase is cumbersome because each financing statement is likely to be on a separate roll of microfilm. ${ }^{44}$ Even a single search is a sizeable task.

6. Search Logic. Each computerized search system has its own search logic. For example, most ignore spaces and punctuation, so that IBM is considered the equivalent of I.B.M or I B M. On a search for Kenneth Brown, some will retrieve filings against $\mathrm{K}$. Brown, Ken Brown, or even K. B. Brown. ${ }^{45}$ In other systems, the search returns only exact matches, so the searcher must specify each variation that is to be retrieved. The search logic employed in a particular system is likely to change over time, and documentation rarely is available. ${ }^{46}$ As a result, it is difficult for a searcher to know precisely what the computer would or would not find.

7. Common Name Overloads. Some UCC filing systems contain millions of records. If the debtor's name is common, a search may turn up dozens of filings against persons who are not the debtor, but have the same name. ${ }^{47}$

42. Id at 7 .

43. If these delays are anticipated by users of the system, they can be eliminated without significant risk. For example, a typical user of the system is a secured creditor who files a financing statement and then conducts a search to ascertain that it has first priority. Although the user cannot be sure it is first until its financing statement (and therefore all prior financing statements) are discoverable, the user can file about a week before it intends to conduct its search. A single search at the time of the loan closing can then demonstrate the user's priority. Other users of the system, such as buyers of the collateral or judgment creditors who seek to levy against it, do not have that option available to them. In any event, to expect casual users of the system to anticipate their search needs by a week is unrealistic.

44. New York is in the process of converting to an optical disk system. An image of each financing statement is scanned into the system and can be retrieved electronically. See Alces Survey (cited in note 4 ).

45. These examples are the subject of question 7 of the Alces Survey. Id.

46. Question 7B of the Alces Survey asked whether such documentation was available. The large majority of states responded in the negative. Id.

47. See, for example, United States v Polk, 822 F2d 871, 872-73 (9th Cir 1987), where it was argued that "The Maricopa County records had so many entries under the name of Polk that 
The searcher must then use other information, usually the debtor's address, to determine which filings are relevant. ${ }^{48}$ If the information in the index is insufficient to make the determination, the user may have to order copies of all of the financing statements or even resort to off-record sources of information. ${ }^{49}$

8. Multiple Searches for a Single Debtor. As was noted above, a filing against an incorrect name, such as a trade name ${ }^{50}$ or one of several names used by a debtor,51 may nevertheless be effective. If the searcher knows of a trade name, alternative name, or alternative spelling by which the debtor is known, the searcher may wish, ${ }^{52}$ or may even be expected by a court, ${ }^{53}$ to conduct additional searches under those names. Thus, a decision to search for filings against one debtor in a single filing office may be a decision to conduct several searches.

The cumulative effect of these problems is that each filing or search is a substantial undertaking that is by no means certain to succeed. Probably few users of the system actually rely on it. Instead, they restrict their lending to debtors they trust and rely primarily on those debtors' representations and contractual duty to notify them of changes in circumstances.

Thus, I suspect that except with regard to the largest secured loans, filers rarely attempt to perform the feats of diligence contemplated by article 9 in order to insure that their filings remain effective. ${ }^{54}$ They do not, for example, verify corporate names with the secretary of state before lending. Nor to they monitor for changes in those names or removal of collateral from the state. Instead, they make an initial filing in what seem most likely to be the correct places and hope for the best. When the system actually works to control an inattentive or dishonest debtor, it comes as virtually a windfall.

someone searching diligently under 'Bruce Polk' would be unlikely to notice entries under 'Roy Bruce Polk.',"

48. Some filings will contain the debtor's social security number or tax identification number. The ABA Task Force Survey discovered that ten states cross reference filings by tax identification number. Alces and Lloyd Report at 16 (cited in note 4).

49. See text accompanying notes 78-81.

50. In In re Glasco, 642 F2d 793, the court held a filing in only the trade name to be effective.

51. See In re Gustafson, 14 UCC Rep Serv 231 (Bankr WD Okla 1973) (financing statement listing the debtor's surname as "Gustavsen" was sufficient despite the fact that the debtor's true name was "Gustafson"); but see Chemical Bank v Title Services, Inc., 708 F Supp 245, 249 (D Minn 1989) ("This court declines to impose a duty on searchers to search under possible misspellings of a debtor's name.").

52. The ABA Task Force concluded that "[a]s a result [of the trade name cases,] lenders must take time to discover trade names and search against them." Alces and Lloyd Report at 9 (cited in note 4).

53. "Any reasonably prudent creditor would have requested the Secretary of State to search financing statements under [the debtor's trade name]." In re Glasco, 642 F2d at 796 . But see Chemical Bank, 708 F Supp 245.

54. My suspicions are based on a few inquiries of lending institutions. Except with regard to very large loans, the practice was to order a UCC search in only the name of the debtor before making the initial disbursement on the loan. No follow-up searches were made. Monitoring of the collateral or the debtor was generally limited to a few situations involving big-ticket inventory or accounts receivable. 
Similarly, I doubt that many searchers assume along with Baird and Jackson that "if the property in question is in the debtor's possession and if no other creditors have filed a financing statement, his claim to that property can have priority over those of other existing and future creditors." Instead, they realize that the probative value of a search depends ultimately on off-record information about the collateral and the debtor, and that in many instances the debtor is the primary source of that information.

As a result, the system performs a quite different function than that envisioned in theory. Its rules are not instructions as to what one must do to obtain and maintain priority. So read, they are completely impractical. Instead, they have become rules of loss allocation.

\section{Computerized Filing and Search Systems}

The design and implementation of the article 9 filing system gave rise to an identifiable set of legal problems. Those legal problems form the core of the typical law school course in secured transactions. In this part, I will attempt to demonstrate that currently available 55 computer technology has the capacity to solve nearly all of those problems. In each of the sections that follow, I describe a legal problem generated by the article 9 filing system, the method by which computer technology could reduce or eliminate the problem, and what kind of changes in the law would be necessary to allow that to occur.

A. Where Should the Records Be Kept? The Debate Over Local, Central, and National Filing

When in 1965 Grant Gilmore referred to the philosophy of "one big filing system," he meant a state-wide, not a national system. ${ }^{56}$ His reference dramatizes the effect of improved communication and transportation systems on commerce and consequently on our thinking about the article 9 filing system. The drafters of article 9 saw the choice to be made as between "statewide" 57 and "local" 58 filing, but they did not make it. Instead, they drafted three alternative subsections for UCC section 9-401, and left the decision to

55. I use the term loosely. The computer technology described in this article has been available for decades and has been in widespread use in similar situations for years. This article is not about the application of "cutting edge" technology. It is about the application of the dominant technology in a legal culture that is highly resistant to technology.

56. Gilmore, Security Interests in Personal Property at 465 (cited in note 3) ("At all events the 'one big filing system' philosophy became the official Code position; in the course of our discussion we shall have occasion to observe how successfully that goal was achieved.").

57. By "state-wide" filing, they meant that there would be a single set of records in the Office of the Secretary of State.

58. By "local" filing, they meant that there would be a set of records in each county or township in the state. 
the various state legislatures and "local considerations of policy."59 They explained:

[State-wide filing would better serve the interests of] the national distributor who wishes to have current information about the credit standing of the thousands of persons he sells to on credit. The more completely the files are centralized on a statewide basis the easier and cheaper it becomes to procure credit information; the more the files are scattered in local filing units, the more burdensome and costly. On the other hand, it can be said that most credit inquiries about local businesses, farmers and consumers come from local sources; convenience is served by having the files locally available and there is no great advantage in centralized filing. ${ }^{60}$

Advocates of a national filing system joined the debate later, ${ }^{61}$ but had little impact. The result is that today there are more than 4,200 separately searchable UCC filing systems. ${ }^{62}$ In which of these systems a filing or search should be made is perhaps the most frequently recurring problem in practice under article 9. The glib suggestion that we "file everywhere" 63 obscures the mind-boggling problem of identifying the many places where filing might be required or helpful and the many subtle barriers to filing. ${ }^{64}$

Development of the capacity to search everywhere probably is the most practical solution to this problem. Computer technology dramatically reduces the cost of electronic transactions, rendering the absurd not only possible, but cost effective. Once they are in electronic form, the entire UCC records of a state can be searched in a few seconds from almost anywhere on the globe. They can be copied in their entirety with a single keystroke.

The power of these systems is so great that our instincts about what will be "efficient" mislead. For example, when I make a single change in the manuscript for this article and save it to disk, the computer does not merely

59. UCC $\S 9-401$ comment 1 . I have always assumed that this was merely a nice way of saying "local politics."

60. Id.

61. See, for example, Gerald T. McLaughlin, "Seek But You May Not Find:" Non-UCC Recorded, Unrecorded and Hidden Security Interests Under Article 9 of the Uniform Commercial Code, 53 Fordham L Rev 953, 971 (1985).

62. There are state-wide systems in $\mathbf{4 9}$ of the $\mathbf{5 0}$ states (all except Georgia) and county-wide systems in the large majority of counties in the United States. In many states, the local UCC filing system is separate from the real property recording system in which fixture filings are required to be made. In addition, each of the 50 states maintains a separate filing system for article 9 security interests against motor vehicles and some maintain separate filing systems for mobile homes and boats. Florida maintains a separate filing system for liquor licenses and holds filing against a liquor license in the article 9 filing system to be neither necessary nor sufficient. See United States $v$. McGurn, 596 So.2d 1042 (Fla 1992). Finally, the federal government maintains separate systems for filing security interests in aircraft, patents, copyrights, ships, and other types of collateral.

63. See, for example, Richard E. Speidel, Robert S. Summers \& James J. White, Commercial Law Teaching Materials 128 (West, 4th ed 1987) ("File everywhere possibly required."). The suggestion is made in many other publications as well.

64. For example, the secured creditor might fear that the debtor will affix the collateral to real estate, thereby forfeiting the secured creditor's priority. Filing in the real estate records might be a solution, but for the fact that the financing statement must contain a description of the real estate. It is virtually inevitable that someone will propose that the secured creditor's solution is to file against all possible real estate.

Cost also remains an important barrier to filing. While the fee payable to the filing officer is usually nominal, the cost to the secured creditor of determining how to file with the particular office and making the filing generally are not. Unless the secured creditor is a frequent filer, filing the same financing statement in three or four offices is likely to cost hundreds of dollars. 
delete the changed material and replace it. It copies the new file over the old, making thousands of transactions where a few dozen might do. The solution to the UCC search problem is similarly counterintuitive.

Two models suggest how the casual searcher might cover more than 4,200 UCC filing systems in a single search. The first, which I will refer to as "private aggregation," is merely an extension of a process that is already occurring. Nearly all states have their article 9 index on computer. ${ }^{65}$ Many sell copies to UCC service companies, ${ }^{66}$ who then make them available on line. It is already possible to sit at computer terminals anywhere and search the UCC filings of more than thirty states.

These private aggregation systems are not yet functional substitutes for the systems maintained by the various filing officers. First, there is a crucial lag time. About two to four weeks elapse between the time a filing is discoverable in the official records and the time it is discoverable in these secondary sources. Second, the records that are sold are only indexes. The full text of the financing statements continues to be available only from the filing offices. Third, these systems rely on their own search logic rather than the search logic employed in the filing office. The systems might find financing statements that would not be found on an official search, but more importantly, they may fail to find financing statements that would be found on an official search.

Each of these limitations could be overcome without the need for additional technology. Filing officers could enter the entire text of each financing statement, transfer files to the service companies more frequently, and publish their search logic. If they did, secondary sources would eventually fuse the many UCC filing systems into a database searchable with a single request.

A second model for accomplishing this fusion is "distributed processing," 67 essentially the same thing as a computer network. The general notion is that "various elements of a data processing system can be partitioned into well defined units which may be located at various logical sites and linked by agreed upon protocols." 68 In a distributed system, a single UCC search request might be processed by hundreds of computers, each in a different filing office. Despite the fact that data are located and processing is accomplished at many sites, to the user it appears to be a single system.

The comparative advantage of private aggregation lies in its flexibility. Once the data are out of the hands of the filing officers, it can be distributed and used in any manner imaginable by competing aggregators. Aggregators may compete on the basis of convenience in delivery systems, search logic,

65. As of Fall 1990, only eight states still had exclusively manual filing and search systems. These states were Arkansas, Delaware, Indiana, Kentucky, New Hampshire, Rhode Island, West Virginia, and Wisconsin. Alces Survey, answers to questions 4 and 5 of questionnaire (cited in note 4).

66. Examples include Prentice Hall Information Services and Lexis.

67. See Harold Lorin, Aspects of Distributed Computer Systems 3-20 (John Wiley \&c Sons, 1980).

68. Id at 3 . 
coordination with other data sources such as credit reports, census information, or real estate recordings, or on other bases.

The comparative advantage of distributed processing probably lies in its ability to synchronize 69 system use. The lag time between filing and availability of information to the aggregators might be reduced from weeks to hours or even minutes. But it could never match the speed with which a single computer program could make the information available. Even very small lag times may make a critical difference in the functioning of the system. If it takes hours before a filing can be confirmed by search, the parties closing a sale transaction are likely to create an escrow. If it takes only minutes, they may wait in the room for confirmation. If it takes only seconds, search confirmation becomes part of the filing process, and many problems of coordination in the closing become moot. ${ }^{70}$

Either model renders the physical location of the records unimportant. States and counties can continue to maintain "their" UCC records; employees can continue to work at the same sites. Neither model requires that filings be made at particular physical locations. As is true in Louisiana today, ${ }^{71}$ a filer might go to a parish (county) office to make a filing that is then transmitted into the state-wide system. As is true in British Columbia today, ${ }^{72}$ regular users of the system could arrange to make such filings from their own offices or from personal computers located anywhere. The debates over state-wide, local, or national filing would remain unresolved, but they would have ceased to matter.

Nationwide searching would open the way for a dramatic simplification of article 9 . The complex rules that currently specify the proper offices in which to file particular financing statements would no longer be necessary. Because a search would discover a filing regardless of the office in which it was made, article 9 could permit it to be made in any filing office. ${ }^{73}$ Multiple filings of the same financing statement would no longer be required. In fact, UCC section 9-401, the bane of many law students and lawyers, could be repealed outright. Nor would it be necessary for creditors to track the movement of debtors or collateral from state to state or county to county to maintain perfection. Most of section 9-103 could be repealed. Along with these

69. The concept of "synchronization" or "concurrency" in database management is discussed in Jeffrey D. Ullman, Principles of Database Systems 2, 324-59 (Computer Science Press, 1980).

70. If hundreds of units contribute to the system, the system's response time can be no faster than the slowest contributor. For example, if a filing were made in the UCC records of Delaware, it would be possible to confirm its priority in time only after the filing was made and the records of every contributor to the aggregated system had been updated and searched up to the moment of that filing. In a well synchronized system, such a search could be conducted almost immediately.

71. Alces Survey, unpaginated yellow form for Louisiana (cited in note 4)

72. Ronald C. C. Cuming, Computerization of Personal Property Security Registries: What the Canadian Experience Presages for the United States, 23 UCC L J 331, 336 (1991) ("In British Columbia, registrations and searches can be effected by remote computer access from any place where long distance telephone communication is available.").

73. This freedom might lead to a healthy competition among filing offices. That competition might be based on price (the amount of the filing fee), the quality of service, or the nature of the services offered (direct filing from remote terminals, credit, error-trapping, etc.). 
sections would go many distinctions among types of collateral that have no significance except in the determination of the proper place to file. ${ }^{74}$

The article 9 filing systems could also be linked to other systems in which article 9 security interests are filed. These include motor vehicle records and federal systems governing copyrights, patents, aircraft, ships, and railroad rolling stock. The linkage would make it possible to discover all security interests against a particular debtor through a single search. It would moot the distinctions among types of collateral that currently provide the basis for division of the filing system into article 9 and non-article 9 components.

\section{B. Identifying Individual Debtors in Filings and Searches}

Article 9 contemplates that filings will be indexed ${ }^{75}$ and searches made by name of the debtor. ${ }^{76}$ While the searcher may find other information helpful, there is no substitute for a correct name. To illustrate, assume that a debtor's name is listed so incorrectly on a financing statement that the statement could not be found in a search that relied solely on the name of the debtor. Further assume that the debtor's address is both correct and unique and that a search by debtor's address would easily discover the financing statement. Not only is the searcher not required to conduct such a search, in many UCC systems, it is impossible. ${ }^{77}$ As the system currently operates, communication is entirely dependent on the ability of filer and searcher to name correctly, or at least sufficiently, the debtor.

Yet, as was discussed above, ${ }^{78}$ individual names are problematic. First, a single name may have many versions. If the filer uses one version and the searcher uses another, the communication may fail. Second, many people may be known by the same name. As a result, a search report may include dozens of irrelevant filings. It may be impractical for the searcher to check each one.

Searchers have dealt with the debtor-identity and common-name overload problems in an intuitive manner that is difficult for the computer to mimic. For example, if the searcher contemplates lending to James Lawrence Smith and the search report lists a filing against $\mathrm{J}$. L. Smith, the searcher first must determine whether to examine the financing statement and finally may have to determine whether J. L. Smith is the same person as James Lawrence Smith. To make the decision, the searcher might consider the address for J. L. Smith shown on the financing statement. Presumably, the address of each debtor is included in the index ${ }^{79}$ for this very purpose. If the searcher is confident that

74. Examples would be the distinction between mobile and ordinary goods, and the distinction between farm equipment and other equipment.

75. See UCC \$ 9-403(4).

76. See id $\$ 9-407(2)$.

77. It would be impossible in systems in which the index is not yet on computer and in systems where the filing officer searches only by debtor name and prohibits users from conducting their own searches.

78. Notes 21-23 and accompanying text.

79. See UCC \$ 9-403(4). 
the debtor has lived and worked in Chicago for the past five years, the searcher might choose to ignore a filing against J. L. Smith that lists a Springfield address. But the searcher does so at his peril. The debtor may be lying about his former addresses. Even a debtor who lives and works in Chicago may have a "mailing address" 80 in Springfield. The point is that to identify debtors under the current system requires that judgment be exercised. ${ }^{81}$ The current search system, based on the names of individual debtors, has its foundations in unstable soil.

As the number of filings in a system increases, so does the problem of distinguishing filings against a particular debtor from filings against debtors with the same or similar names. For example, in a small system, the searcher may be able to examine each filing against a debtor with the surname "Alexander" to determine which filings are against the Alexander who is the subject of the search. But in a large system, the number of such filings will render that technique unusable. As the article 9 data bases are aggregated nationally, the number of filings examined will be much larger than that of any state system. New techniques for dealing with the problems of same and similar names will have to be found.

One promising approach is to identify individual debtors by social security number. While it is not entirely clear whether a social security number uniquely identifies an individual, ${ }^{82}$ it comes much closer to doing so than a name. A search by social security number would turn up few irrelevant filings.

If the numbers are used, it is difficult to determine what legal significance should be attached to them. Inclusion of the debtor's social security number on a financing statement currently is permitted, but not required. ${ }^{83}$ Many filers include them. Some filing officers cross-reference financing statements by social security number ${ }^{84}$ thereby increasing the likelihood that they will be discovered in a search.

The ABA Task Force has suggested substituting the debtor's tax identification number for the debtor's name in the search process. (Though the Task Force did not directly recommend the use of social security numbers for individual debtors, that is the implication, because an individual's social security number is his or her tax identification number. ${ }^{85}$ Under the Task Force's proposal, financing statements would be effective only if they bore

80. The requirement that the financing statement give the "mailing address" of the debtor is found in UCC $\$ 9-402(1)$.

81. See note 38 .

82. Each social security number is supposed to be assigned to only one person and each person is supposed to have only one number. Through administrative errors, some numbers have been assigned to more than one person. It also seems likely that some people have obtained more than one number through fraud. Nevertheless, many large databases operate successfully on the assumption that social security numbers uniquely identify individuals.

83. UCC \& 9-402(1).

84. Alces and Lloyd Report at app 6 (cited in note 4).

85. Their report refers to the debtor's "tax identification number." Alces and Lloyd Report at 24 (cited in note 4). I refer to "social security number" in order to distinguish the case of individual debtors where use of numbers is in fact necessary from the case of corporate debtors where it is not. The distinction is employed in the next section. 
correct social security numbers. Searches would be conducted by social security number, while debtors' names would be relegated to the status currently accorded to addresses. That is, a search report would include a financing statement only if the numbers matched.

The Task Force found weaknesses in its own proposal. ${ }^{86}$ It noted that the process of identifying debtors would be highly abstract and therefore prone to clerical errors. The Task Force also predicted that it would "cause major transition problems."

Another weakness with a system that substitutes social security numbers for names is that social security numbers are more difficult to verify. For example, assume that Jane Smith wants to defraud Bank by borrowing against collateral that is already encumbered. As the system currently operates, to prevent Bank from discovering the prior filing, she would have to use a false name in dealing with Bank. If Bank "knows its borrower" to any significant degree, that will be impossible. But if searches were conducted by social security numbers, she could conceal the prior filing merely by using a clean social security number-that is, one against which there are no UCC filings. Bank would have to discover, perhaps through credit reports, cross-checking of credit accounts, or other means, that the social security number she gave them was not correct.

Finally, while everyone has a name, not everyone has a social security number. For some debtors, borrowing would involve the additional step of setting up a social security account. The problem might be significant with regard to borrowers who are not residents of the United States.

A better solution would be to require that the debtor's name and social security number both appear on financing statements and search requests, and that both be used in the search process. Searches would discover a financing statement if either number or name matched. This redundant search process would overcome most errors and variations in the forms of debtors' names. Because it includes the same search by debtor's name that is currently performed, it would pick up irrelevant filings at least as frequently as in the current system. But it would not pick up any significant number of additional filings. ${ }^{87}$ The social security number would assist in analyzing the search report by making it easier to determine whether the filing is against the subject of the search. Part of that process might even be automated. Because names would remain in use, in the relatively uncommon case in which the debtor has not been issued a social security number, a numberless financing statement could be accepted for filing and discovered in a search.

Such a system would require more computer processing time. Creditors and searchers would have to discover their debtors' social security numbers, but most do so already. Both costs probably would be far more than offset by

86. Id.

87. While the search would still pick up financing statements filed against irrelevant debtors with the same name, irrelevant debtors would have the same social security number only through clerical error. Presumably, those clerical errors would not be significant in number. 
the increased accuracy of the system and by the time saved in interpreting search results. ${ }^{88}$

\section{Identifying Corporate Debtors in Filings and Searches}

Creditors filing against corporations encounter a different kind of name problem. Businesses are often conducted by corporate groups, and it may be difficult to determine which member of the group owns or will own the collateral. In addition, many, if not most, businesses employ unregistered trade names that can easily be confused with the corporate name. Judging from the number of reported opinions, the amount of litigation over errors in the debtor's name has been considerable. ${ }^{89}$

The problem of identifying corporate debtors is more susceptible to technological solution than that of identifying individual debtors. The vast majority of corporations that are debtors under article 9 are incorporated under the laws of one of the fifty states. Although corporations formed in different states may have exactly the same name, that is not true of corporations formed in the same state. Each state will charter only one corporation under a particular name. Thus, the name of a corporate debtor together with the name of the state in which it is incorporated is a unique identifier, sufficient to distinguish that corporation from all other domestic corporations. ${ }^{90}$ If both pieces of information correctly appear on financing statements and search requests, a simple match determines whether a financing statement already on file refers to the debtor that is the subject of the search.

Although the computer cannot tell whether a corporate name and state of incorporation are correct, through various error-trapping processes it sometimes can determine that they are incorrect. If the computer makes the determination while the user is entering the information, it can offer the user the opportunity to substitute correct information. In effect, the computer will prevent the entry of certain kinds of erroneous information.

To illustrate, assume that the computer system of the Delaware Secretary of State is linked to the corporate records of that state. A creditor sits at one

88. Even though their legal position in doing so would be ambiguous, searchers would undoubtedly use social security numbers as the basis for ignoring what otherwise would be considered possibly relevant filings requiring investigation. For example, a searcher might choose to ignore a filing against a John Lawrence Smith that showed both a social security number and an address different from that of the debtor.

89. The reported opinions are themselves indexed in 9-401 to 9-402 Uniform Commercial Code Case Digest, ๆ 9402.4-.6 (Callaghan, 1989).

90. Federal tax identification numbers are sometimes used to identify further the corporation debtor mentioned in a financing statement. Based on the analogy to social security numbers, it is tempting to recommend requiring that tax identification be included on all filings and incorporated into the search process. The analogy is unconvincing. The critical difference is that the name of a natural person is not necessarily unique, necessitating the addition of a unique identifier. But the corporate name plus state of incorporation is unique, making the tax identification number entirely redundant. The problems with the use of numbers generally are discussed in the text accompanying notes 86-88. The argument against the use of tax identification numbers is particularly strong if, as this writer understands is the case, some corporations have more than one tax identification number. 
of the computer terminals and attempts to file a financing statement against Wismuth, Inc. As soon as the name is entered, the data base management program "looks up" Wismuth, Inc., in the corporate records. If such a corporation does not exist, the program alerts the filer immediately. ${ }^{91}$ If such a corporation does exist, the program can offer the filer a peek at the corporate information. That may enable the filer to determine whether the corporation named is in fact the one intended.

If each filing office is linked to the corporate records of all states, the identity check can be performed on all filings against debtors incorporated in any state. Errors in the naming of corporate debtors in financing statements and searches, as opposed to errors that mistake one corporation for another, could be virtually eliminated.

\section{Coping with Changes of Name, Identity, or Corporate Structure}

As was discussed in Part I, financing statements for the most part remain legally effective even though changes in name, identity, or corporate structure have rendered them seriously misleading and, as a practical matter, undiscoverable. ${ }^{92}$ For example, assume that Oldname, Inc., granted a security interest in its business equipment to Firstbank, changed its name to Newname, Inc., and then applied to Secondbank for a loan to be secured by the equipment. Secondbank could check the corporate records, discover the change of name, search in the former name, and discover Firstbank's interest. But unless the loan is large, Secondbank is unlikely to do so.

If the filing office were linked to the corporate records, the program could take care of this problem for Secondbank. It could discover the prior names by which Newname has been known and search the UCC records under those names during the relevant periods. All of this could be accomplished even without a request from Secondbank, and unless something relevant were discovered, the program need not even mention any of it to Secondbank. Because the searcher in such a system would be able to discover filings in the former corporate name, those filings could remain effective despite the change of name. Secured creditors would no longer have to monitor their debtors for changes of name or corporate structure.

\section{E. Lapse and Continuation}

The theory of article 9 is that the public files of financing statements are "self clearing." 93 That is, termination statements are seldom necessary because, at the end of five years, financing statements cease to be effective (lapse). The Code expressly authorizes the filing officer to remove and

91. It is probably desirable to allow the filer to over-ride the program's error message to deal with the situation where Wismuth is in the process of incorporation and the filer wants to anticipate it.

92. See UCC $\$ 9-402(7)$.

93. Id $\$ 9-403$ comment 2 . 
destroy any financing statement one year after lapse. ${ }^{94}$ While this selfclearing aspect of the system is probably a welcome relief for administrators, it necessitates carefully coordinated action by filers who wish to continue their perfection beyond the five-year period. UCC section 9-403(3) creates a sixmonth window of time immediately before lapse during which the creditor must file a continuation statement. Filing either early or late is fatal. ${ }^{95}$ It has even been held that the timely filing of an ordinary financing statement rather than a continuation statement is fatal, though no one was in any way prejudiced. ${ }^{96}$ This delicate process can be complicated further if a bankruptcy case is pending against the debtor during the six-month window. ${ }^{97}$

This cumbersome self-clearing process is a product of the technology of its time. In a paper system, it is burdensome to retain records for an extensive period of time. It is also difficult to remove records from the system and destroy them if each has to be dealt with individually. UCC section 9-403(3) addresses this problem by authorizing the destruction of all records filed more than six years earlier. Special attention has to be given only to the relatively small number of those records that have been continued. The burden is on the continuation filers to bring them to the attention of the filing officers at times convenient to the latter.

Computers, on the other hand, destroy records at the blink of an eye. ${ }^{98}$ Picking though records periodically to determine which meet the criteria for destruction is a job for which they are well suited. Thus, in the fully computerized Canadian systems for the registration (filing) of security interests, filers are now permitted to choose the periods for which the registrations will be effective. ${ }^{99}$ The registration fee is commensurate with the length of the period selected. ${ }^{100}$ Adoption of this system under the UCC would virtually eliminate the tricky process of continuation, make the system considerably more convenient for filers, and greatly reduce the likelihood of unintended lapse.

94. Id \& 9-403(3).

95. See In re Adam, 96 Bankr 249 (Bankr ND 1989) (holding a prematurely filed financing statement ineffective); In re Super Treads, Inc., 7 Bankr 532 (Bankr MD Ga 1980) (holding continuation statement filed on fifth anniversary of filing of financing statement ineffective).

96. In re Hays, 47 Bankr 546 (Bankr ND Ohio 1985).

97. It has been held that the filing of a continuation statement during a bankruptcy case violates the automatic stay. In re Bond Enterprises, Bankr L Rep (CCH) ף 70,811 (Bankr NM 1985). The security interest remains perfected until 60 days after termination of the bankruptcy case. UCC $\S 9$ 403(2). But it is not clear when a case under chapter 11 of the bankruptcy code is terminated. Arguably it might be either the time of confirmation or the effective date of the plan, see General Electric Credit Corp. $v$ Nardulli $\mathcal{E}$ Sons, 836 F2d 184 (3d Cir 1987), or the time of entry of the final decree. See Bankruptcy Rule 3022. In any event, under a literal reading of UCC \$ 9-403, a continuation statement can only be filed during the five-year period, not during the 60 days.

98. As anyone who has ever lost a word processing document can attest.

99. Cuming, 23 UCC L J at 337-38 (cited in note 72).

100. Id at 338. Cuming reports that in British Columbia, a registering party pays a $\$ 3$ processing fee and $\$ 5$ per year or $\$ 400$ to infinity. Id at $338 \mathrm{n} 34$. 


\section{F. Negative Covenants and Continuous Searching}

Security agreements commonly provide that the debtor will keep the collateral free of all liens, security interests, or encumbrances other than those in favor of the secured party. These "negative covenants" are included for a variety of reasons. The parties may intend that the secured party will provide all of the financing necessary for the debtor's business. Secured parties may want to prohibit prior liens because they threaten the parties' ability to recover the loan through sale of the collateral. Secured parties may fear subsequent liens because they threaten unwanted changes in possession of collateral. If unexpected liens appear, secured parties may want the right to declare defaults and thereby generate leverage for dealing with whatever problems exist.

As most filing systems currently operate, a secured party is without practical means for discovering liens that come onto the public record after its own filing. In some systems, the secured party would have to request searches periodically. In other systems, the secured party can monitor the record through credit reporting services that examine each new filing on behalf of a large number of similar clients. But even this second kind of monitoring is so expensive that it is not cost-effective in any but the largest cases.

In a computerized system, it is relatively easy continuously to monitor the records for new filings against a particular debtor. As the Secretary of State adds each financing statement or other document to the system, the computer checks it against a list of parties who have requested notice of filings against particular debtors. If a match occurs, the system sends notice to the requestor either electronically or by mail. While this kind of service is unlikely to be offered by filing officers, it is likely to be available through private vendors who are able to purchase a copy of the filing officer's data base.

The availability of continuous searching would suggest a reappraisal of UCC section 9-312(3) governing purchase money security interests in inventory. That section requires suppliers who wish to retain purchase money security interests in goods that will become part of their debtors' inventory to give off-record notification to inventory financiers who have previously filed financing statements against their debtors. The notification must be given before the debtors receive possession of the goods. A comment to that section explains the reason for the notification requirement:

[T]ypically the arrangement between an inventory secured party and his debtor will require the secured party to make periodic advances against incoming inventory or periodic releases of old inventory as new inventory is received. A fraudulent debtor may apply to the secured party for advances even though he has already given a security interest in the inventory to another secured party. The notification requirement protects the inventory financier in such a situation: if he has received notification, he will presumably not make an advance; if he has not received notification . . . any advance he may make will have priority. ${ }^{101}$

101. UCC $\S 9-312$ comment 3 . 
The comment explains why an inventory secured party with such a financing arrangement needs to be aware of purchase money security interests in inventory as the inventory is received by the debtor. But it does not explain why it is the duty of the purchase money lender to notify the inventory secured party rather than the duty of the inventory secured party to discover the purchase money lender's already-filed financing statement. ${ }^{102}$ Undoubtedly, the answer is that in the absence of computerization, the inventory secured party's task of continuously searching for new filings by purchase money suppliers is far more burdensome than the purchase money supplier's task of sending one notice every five years.

Once the filing system is computerized, an inventory secured party who fears that the debtor will use the same collateral twice will be able to monitor the records cheaply and continuously. Because the purchase money supplier must place a filing on record before the debtor receives possession of the collateral, ${ }^{103}$ the inventory secured lender who continuously monitors the records could easily discover the supplier's security interest in time to avoid disbursing against already encumbered collateral. ${ }^{104}$ In such a system, it will be more efficient to place on the inventory secured party the burden of continuously monitoring the records to discover purchase money suppliers than to place on the purchase money suppliers the burden of notifying inventory secured parties. Under the current rule, purchase money suppliers must notify inventory secured lenders in every case. Because the inventory secured party does not bear the cost of notice, it has neither the incentive nor the ability to dispense with notice when it is unnecessary. Under a rule that placed the burden on inventory secured parties to protect themselves by monitoring computerized records, the inventory secured party would be in a position to determine whether the risk of fraud was great enough to warrant the actual cost of guarding against it. The cost to purchase money suppliers under the current system of sending notification in every case probably far exceeds the costs of the monitoring for which inventory lenders in a computerized system would actually be willing to pay.

By imposing high transaction costs, the current scheme of UCC section 9312 makes it difficult for suppliers to retain security interests in the goods they sell. Notification not only brings the supplier's attempt to the attention of the inventory financier, it does so in a manner more intrusive than that required for other types of security interests. The consequences of receipt of such a notice are difficult for the inventory financier to assess. ${ }^{105}$ Many

102. UCC $\S 9-312(3)$ requires that the purchase money secured party "be perfected at the time the debtor receives possession of the inventory" and give the off-record notification.

103. I have assumed that filing before the debtor receives possession will continue to be a condition for acquiring purchase money priority in inventory.

104. Whatever brief lag time there might be in a computerized filing system would probably be offset by the lag time between receipt of inventory by the debtor and the inventory lender's routine disbursement against that inventory.

105. For example, even if the amount of purchase money financing were small, the inventory secured lender could not ignore the notice. The amount might increase in the future, without further notice. 
inventory financiers avoid the problem by including in the security agreement a covenant that the debtor will not suffer liens other than those of the inventory financier against any part of its inventory. Even in the absence of such a covenant, debtors are reluctant to grant security interests that will result in receipt of such a notice. They fear that receipt will adversely affect their primary lending relationship. These considerations may largely explain why suppliers rarely retain security interests in the goods they sell.

Elimination of the notification requirement will put suppliers in a better position to negotiate security interests in the goods they sell. But given the prevalence of negative covenants in inventory security agreements, it is unlikely to result in a dramatic increase in purchase money inventory lending.

\section{G. Electronic Filing}

As of April 1, 1992, Iowa became the first state in the United States to permit the filing of financing statements electronically. ${ }^{106}$ Authorized parties can transmit the information for various kinds of filings to the Secretary of State by telephone. ${ }^{107}$ The transmission constitutes filing; it need not be followed by hard copy.

A system that permits electronic filing has several advantages over a system that permits hard copy to be filed and then entered to the electronic database. Once a hard copy original is created, it is the best evidence of what was filed. Resort to so authoritative a document is inevitable; yet resort is likely to be cumbersome. An electronic "original," on the other hand, can be retrieved, copied, or transmitted easily and inexpensively.

Under current practice, filings containing particular kinds of errors are routinely rejected by the filing officers. ${ }^{108}$ The rejection may occur immediately upon physical presentation of the financing statement to the filing officer, or it may occur at such later time that the filing officer discovers the error. ${ }^{109}$ In the interim, secured parties who have relied on the filing officer's acceptance of the filing may be prejudiced. ${ }^{110}$

By contrast, electronic filings can be machine checked automatically as they are received. (The process is sometimes referred to as "errortrapping.") Whether particular types of errors will result in rejection would

106. Barkley Clark, Latest Technology Used by UCC Filing Offices, 7 Secured Lending Alert 1, 1 (March 1991).

107. Iowa Administrative Code, $\$ \S 721-6.1$ et seq (Dec 26, 1990).

108. Barkley Clark, Beware of Rejections by UCC Filing Offices, 7 Secured Lending Alert 4, 4 (March 1991).

109. The widespread practice of rejecting filings after they have been accepted and stamped with a date and time of filing has been documented by the ABA Task Force. See Alces and Lloyd Report at 16 (cited in note 4 ).

110. In most cases, the filing officer will require that the filer submit a correct filing. If the rejection does not occur immediately upon filing, other filings may intervene or a grace period for relation back may expire. In either event, the filer may lose its priority. If the rejection was in error, the situation is even more disconcerting. The filer may be left to a doubtful legal remedy against the filing officer or the filing officer may backdate the rejected filing, thus elevating it to priority over the innocent intervenor. See id at 8. 
depend on their nature and the policies of the particular filing office. The key is that the filer can be notified immediately of any machine-discoverable error and be given the opportunity to correct it. For example, if the financing statement did not contain an address for the debtor, the program would generate an error message at the time the filing was made. The filer could take corrective action before suffering prejudice. Errors common to hard copy filings, such as omission of the debtor's signature, 11 the debtor's mailing address, or the description of the collateral would be virtually impossible to make in an electronic filing system.

\section{H. Should There Be Official Search Logic?}

If a financing statement is insufficient in form and the debtor files bankruptcy, the trustee or the debtor can avoid the security interest and render the creditor unsecured. ${ }^{112}$ They can do so even though no creditor was injured or misled. Given the draconian nature of this remedy, knowledgeable secured parties are anxious to file effectively.

Nevertheless, errors abound. Some result from the indeterminacy of the current system for identifying individual debtors. ${ }^{13}$ Others are truly errors of identity. Probably most are clerical errors. The error-trapping techniques of database management are capable of greatly reducing the number of errors in filed documents. But some kinds of errors are not susceptible to those techniques. They will continue to occur.

A simplistic approach would be to conclude that if the debtor's name or other necessary identifying information is incorrect, the filing is ineffective. In reality, such an approach is "commercially and politically unacceptable." 114 If the error would not materially impede a searcher in discovering the filing or understanding its relevance, current law and opinion concur in the view that it should not vitiate the filing. Errors of an inconsequential nature must be tolerated.

This judgment is reflected in the provision of UCC section 9-402(8) that "a financing statement substantially complying with the requirements . . . is effective even though it contains minor errors which are not seriously misleading." At first glance, this standard may appear to address the filing rather than the search process. But on reflection it should be apparent that if a financing statement contains errors, it is virtually impossible to assess their significance without consideration of the manner in which searches are conducted. For example, in In re Tyler 115 the correct name of the debtor was Tri-State Molded Plastics, Inc. A filing against "Tri-State Moulded Plastics, Inc." was held to be seriously misleading. Although this minor error in

111. In the Iowa system, the debtor's signature is made by repeating the debtor's name in a particular box on the computer screen. By transmitting the name the filer warrants that it has written authority to make this signature on behalf of the debtor.

112. Bankruptcy Code $\$$ 544(a).

113. See text accompanying notes 78-81.

114. Cuming, 23 UCC L J at 339 (cited in note 72).

115. 23 Bankr at 807, 809-10. 
spelling would not have prevented discovery of the financing statement in a search conducted by hand, ${ }^{116}$ the filing officer in that case conducted all searches by computer. The search logic used was such that a search in the correct name of the company would not have discovered the financing statement filed in the incorrect name, despite the similarity between the two.

A misspelling of the debtor's name does not necessarily prevent a computer search from retrieving the filing. Many search programs treat common misspellings of a word as the word's equivalent and retrieve filings accordingly. So, for example, in the Saskatchewan security interest registration system, the search program treats "Smith" as the equivalent of "Smyth" and "Schmutz" as the equivalent of "Schmutt."117 Similarly, the search computer might be programmed so that a search for filings against "James L. Smith" would retrieve filings against "J. L. Smith," "JL Smith," or "J. Smith." 118

In a jurisdiction where searchers are not permitted direct access to the files and the filing officer conducts all searches by computer, a searcher can discover only those filings that will be retrieved by the filing officer's computer program. In that jurisdiction, an error in filing would be absolutely misleading if it prevented the computer from retrieving the financing statement in response to a properly framed search, ${ }^{119}$ but not misleading at all if it did not. In such a jurisdiction, the search logic of the filing officer's computer might effectively and precisely define "seriously misleading."120

If, on the other hand, the filing officer sells copies of the filing system data to private vendors, other search methods may be applied. For example, the UCC indexes of many states are already available for search on Lexis. The

116. For example, if the search were in a fling cabinet in which financing statements were ordered alphabetically by the name of the debtor, this particular financing statement probably would have been in exactly the same location with the misspelling as without it. By looking in the correct place in the system, the searcher would have found the incorrect. statement. Because the name on the statement was so unusual, the searcher probably would have suspected an error in spelling and looked at the address. If the address matched that of the company being researched, the searcher could easily have deduced that there had been an error in spelling.

117. Cuming, 23 UCC L J at 341 n42 (cited in note 72).

118. Judging from the results of the Task Force survey, the search logic now in use in article 9 filing systems is at a very low level of sophistication. Many of the systems strip punctuation and spacing from the data so that I.B.M., I B M and IBM will be equivalents. But beyond that, most of the systems require an exact match between the search name and the filing name. See Alces Survey, answers to question 7 of questionnaire (cited in note 4).

119. It is conceivable, but unlikely, that a search would be considered to have been framed properly only if it anticipated particular errors on the part of filers, such as common misspellings. In most jurisdictions, the anticipation would be accomplished by requesting that the search be conducted in additional names.

120. See In re Tyler, 23 Bankr at 809. In re McGovern Automotive Specialty, Inc., 51 Bankr 51 1, 513-14 (Bankr ED Pa 1985). Both cases stand for the proposition that an error is seriously misleading if it would cause a party searching under the correct name in the relevant index to fail to find the financing statement. The $A B A$ Task Force has suggested that this proposition be specified in a comment to the UCC. Alces and Lloyd Report (cited in note 4).

Despite their critical importance in defining the standards for an effective filing, the search logics employed in computer searches in most states are determined privately by the filing officer and are not published. One exception is Texas, which publishes its search logic. Alces Survey, question 7 on Texas questionnaire (cited in note 4). 
search logic employed is the same boolean word search logic offered by Lexis for searching court opinions and law review articles. Unlike many official searches, the Lexis search can include addresses and descriptions of collateral. But the Lexis search system lacks features common to a system specifically designed for UCC records. A search against "J Smith" does not retrieve a filing against "John Smith."

As UCC searches in the records maintained by private vendors become more common, those vendors will develop search programs specifically designed for that purpose. Considerable efficiencies might be obtained. One objective of such a program might be to anticipate and overcome errors in filing. That objective could be accomplished by retrieving records that are similar to the subject of the search, but not a perfect match. The limit on this technique is that each record retrieved must then be evaluated. Sophisticated search software could assist in that evaluation, considering information from several different parts of the financing statement in relation to one another, taking advantage of links to other databases that might give additional meaning to the UCC data, and relating both to additional information supplied by the search initiator about the debtor or the situation. For example, if the search initiator were confident that the debtor had never had an address outside a particular geographical area, the program might devalue filings listing addresses outside that area. The program might access other databases to discover name changes, to relate addresses to zip codes, or to gauge the statistical likelihood that a particular pair of letters or numbers would be transposed inadvertently. In particular circumstances, it might ask the search initiator for additional information that bears on the search problem. Obviously, such a program might overcome filing errors that the filing officer's program could not. Conversely, in paring down the number of filings that must be personally evaluated by the search initiator, the program might discard an erroneous filing that would be retrieved in a much less sophisticated official search.

The existence of official search logic could inhibit the development of such software. The official search logic would for all practical purposes define "seriously misleading." That is, if a searcher employed it and did not discover a particular financing statement, the searcher could be reasonably confident that the financing statement would not be held effective. ${ }^{121} \mathrm{~A}$ searcher in these circumstances might not have much incentive to do a more thorough search.

More sophisticated software could not be of much help. If a filing could be retrieved by the official search logic, probably most searchers would want to examine it personally rather than have the final decision made by the software. As a result, the market for innovative search software might be considerably smaller than it would have been in the absence of official search logic.

121. But see note 119. 
At the same time, the fact that the state has adopted official search logic could substantially increase the searcher's task. When the official search logic would retrieve a filing, that effectively would impose on the searcher a duty to examine it. To understand how this occurs, consider the analogous situation in a filing system in which searches are conducted by hand. While searching in such a system, the searcher may notice a filing that does not meet the search criteria. The searcher may notice it because it is physically adjacent to a filing that does meet the criteria or because it is physically located in the place where a correct filing would have been. It is a short but nevertheless troubling leap to the conclusion that the searcher "ought" to notice such a filing. By making this leap, courts have found that a searcher looking for filings against Henry Platt should have noticed a filing against Platt Fur Company, ${ }^{122}$ and that a searcher looking for filings against John and Larry Alexander should have noticed a filing against Alexander Farms. ${ }^{123}$ The principle established by cases such as these may be that once a financing statement is separated from the mass of records, the searcher must examine it with special care. The searcher cannot stop reading just because the statement does not meet the search criteria. By carelessly sanctioning statistically insignificant relationships, an official search logic might condemn legions of "Smyth" searchers to plowing through myriads of "Smith" entries.

One advantage of official search logic is that it apportions responsibility between the filer and searcher, enabling each to concentrate on a narrower range of problems. An official search can sharply narrow the number of filings to which the searcher must devote attention. The search logic tells the filer exactly what errors will not be tolerated; the frequent filer can concentrate on reducing those errors.

\section{III}

\section{The Demand for Data in a Computerized System}

Computerization of the filing system will enable filers to maintain effective filings and enable searchers to find them. The processes of filing and searching will be accelerated and demystified. Like any good software, the article 9 filing and search system will become virtually transparent. ${ }^{124}$ That is, users will no longer have the sensation that they are working with the software. Their sensation will be that they are working with the data.

As users finally obtain this view, the basic inadequacies of the data will become apparent. Searchers typically consult the article 9 filing system because they plan to extend credit. In most cases, their loans will be "asset based." That is, they have evaluated particular collateral, contracted for a security interest in it, and are relying on the priority of that interest as protection in the event of default. What they want to know is whether

122. In re Platt, 257 F Supp 478 (ED Pa 1966).

123. In re Alexander, 39 Bankr 110 (Bankr ND 1984).

124. See, for example, Lorin, Aspects of Distributed Computer Systems at 9-10 (cited in note 67). 
competing interests have claimed priority in that collateral. But the article 9 filing system data cannot answer question. It can answer only the narrower question of whether there is a financing statement on file against a particular name.

To get from the system the answer the searcher seeks, the searcher must gather and use three kinds of information from off-record sources. The first is information linking the collateral to its current and former owners. The second is information linking the collateral inspected by the searcher to descriptions in filed financing statements. The third is information about liens other than security interests that may encumber the collateral.

\section{A. The Owner-to-Collateral Link}

Article 9 implicitly assumes that searches will be conducted by name of the "debtor."125 But a search result showing no filing against the person to whom the loan is to be made does not necessarily indicate anything about the collateral. To know that the collateral is free and clear of liens, the searcher must know that the debtor in whose name the search was conducted was the sole owner of the collateral during the entire relevant period.

What period is relevant? Unfortunately, it is the entire period from the enactment of the Code or the creation of the collateral, whichever is later, to the time the searcher's own filing is placed on the record. To demonstrate, assume that $\mathrm{O}$, the original owner of the collateral, granted a security interest to Firstbank in 1970. Later that year, and without authorization from Firstbank, $O$ sold a portion of the collateral to A outside the ordinary course of business. Pursuant to UCC section 9-306(2), the security interest continued in the collateral purchased by $A$. Pursuant to the last sentence of UCC section 9-402(7), Firstbank's financing statement remained effective with regard to the collateral, even though no filing was ever made against $A$. In the ensuing years, Firstbank continued to loan money to $O$ and Firstbank filed timely continuation statements. In 1991, A contracted to sell its portion of the collateral to D. D applied to Secondbank for financing, offering the collateral as security. If Secondbank had made the loan, its security interest would have been subordinate to that of Firstbank. ${ }^{126}$ Yet the only way it could have discovered Firstbank's filing would have been to trace the ownership of the collateral to $O$ and search under $O$ 's name. Thus, to locate all effective financing statements in the system, the searcher must know not only the name of the current owner of the collateral, but also the names of all former owners.

125. This assumption is reflected in the requirement of UCC $\$ 9-403(4)$ that filings be indexed in the name of the debtor, in the requirement of UCC $\$ 9-407(2)$ that search reports be as to "a particular debtor," in the UCC $\$$ 9-402(1) failure to require descriptions of collateral adequate to support searches, and in numerous other provisions. See also Chemical Bankv Title Services, Inc., $708 \mathrm{~F}$ Supp 245, 249 (D Minn 1989) (["The debtor's name] is the key to the indexing upon which the entire notice system relies.").

126. Firstbank has priority because it was the first to file or perfect against this collateral. UCC $\S 9-312(5)$. 
Unlike real estate recording systems, article 9 filing systems do not contain information on ownership or transfers of ownership. The searcher must identify the owners of the collateral from off-record sources. Ordinarily, the searcher will ask the debtor for this information. In addition, the searcher may require the debtor to furnish back-up documentation such as bills of sale, equipment lists, or receipts for the payment of personal property taxes. In extreme cases, the searcher may make off-record inquiries of other persons.

Transfer of ownership information has long been part of other personal property filing systems, such as those covering automobiles, aircraft, and patents. ${ }^{127}$ Each of those systems represents an exception from article 9 for particular types of collateral. The types covered by those systems are better suited to public record title tracking than the type that remain under article 9.128 Specifically, automobiles, aircraft, and patents all share three characteristics. First, they are stable in form. Rarely are they divided into parts or commingled into a mass. In these respects, they differ from unsuitable collateral, such as a pool of oil. The oil may be commingled with oil from other pools, divided among numerous tanks, or both. Second, each item of suitable collateral is relatively expensive, making it easy to cost justify keeping track of it. One can uniquely tag an automobile for the purpose of identifying it; under current technology, it is difficult uniquely to tag a grain of wheat. Third, suitable collateral does not change in use and appearance during its useful life. When an aircraft ceases to be usable as such, it is nearly worthless. Oil, on the other hand, may become plastic and eventually be incorporated into an automobile. These changes make it difficult to relate the collateral to public record descriptions of it.

Whether it is worth using public records to track ownership of particular items of personal property is a function of the technology with which that can be accomplished. Computer technology has radically changed the equation in ways that have not been fully exploited. For example, bar coding technology has made it possible for grocery and drug stores to track individual tubes of toothpaste. Whether there should be a filing system for titles to personal property depends not only on the inherent "suitability" of the property, ${ }^{129}$ but also on the current cost of tracking and the benefits to be gained from tracking. Put in economic terms, are the costs of verifying title to particular kinds of personal property off record, together with the losses from failure to verify it, more or less than the cost of filing in, searching in, and maintaining a personal property title-filing system for that type of property?

While this question is unlikely to be resolved by empirical research, a limited version of it is capable of resolution in the marketplace. Article 9

127. The best example is the "certificate of title" systems governing automobiles. These systems ostensibly allow perfection by recording on the certificate of title. But only the filing officer can make the recording and the filing officer retains a copy that for all practical purposes governs the rights of persons who deal with the automobile. Functionally, the system is little different from the article 9 filing system, except that transfers of title are included.

128. See Baird \& Jackson, $13 \mathrm{~J}$ Legal Studies at 299, 306 (cited in note 2).

129. Id ("Not all types of property are equally suited to an informational system based on files."). 
could be amended to permit, but not require, (1) the filing of documents transferring title to personal property and (2) the searching of those records. Interested parties could then purchase as much of these filing and searching services as would be cost-effective. Initially, the primary incentive to file title documents would be to memorialize the transactions. Both because the public record cannot be tampered with after it is created and because its contents cannot be concealed, it is a more credible source of proof than private business records. ${ }^{130}$

For example, assume that the debtor applies for a secured loan and represents that particular documents constitute its source of title. The lender may take copies of the documents and place them in its own file. But if additional conflicting documents surface later, the contents of the lender's file will then be self-serving, entirely under the lender's control and therefore of limited credibility. The lender's situation would be considerably better if at the time the loan was made, the lender had required that the debtor file the documents in its chain of title. The filing would have occurred at a time when the documents were not self-serving, ${ }^{131}$ and it would be clear that the documents had not been altered at some later time. The holder of the conflicting claim might even be estopped by its knowledge of the public record. If the debtor were engaged in fraud, the filing would have made the fraud public and perhaps led to its discovery. ${ }^{132}$ Thus, permitting the filing of title documents, even without requiring it or imposing a penalty on nonfilers, would probably lead to a substantial amount of such filing, just as it has with regard to leases.

\section{B. The Description-to-Collateral Link}

Under the "notice filing" philosophy of article 9, financing statements need only indicate the types of collateral covered. They need not even describe the collateral, much less enable the searcher to identify it. ${ }^{133}$ Professor Shanker argued that the laxness in the description requirement has resulted in actual descriptions that are so general as to be virtually useless in the search process. ${ }^{134}$ In effect, an article 9 search can discover who may have

130. Both the records and certificates relating to them are admissible in evidence in some circumstances in which private business records would be inadmissible. See generally Charles Tilford McCormick, McCormick on Evidence 888-98 (West, 3d ed 1984).

131. Before the lender relied on the documents by disbursing the loan proceeds, the lender's self-interest would be in knowing whether title was good. The lender would have nothing to gain and much to lose by attempting to create a false title.

132. For example, a common type of fraud is to claim the ownership of the property of another and then borrow against it. If most lenders required, as a condition of the loan, that their debtors deraign their titles in the filing system, putative transferees would be in a position to discover the fraud merely by searching the record. The fraudulent debtor could solve that problem by inventing a fictitious transferor, but in so doing, would expose itself to other risks of discovery. Moreover, the debtor's fraudulent representations as to title would be memorialized in the article 9 filing system, making it easy to prove that they were made. See Mooney, 39 Ala L Rev at 683, 751 (cited in note 2).

133. See UCC \$ 9-402(1).

134. Shanker advocates abandonment of the description requirement. Morris G. Shanker, $A$ Proposal for a Simplified All-Embracing Security Interest, 14 UCC L J 23, 25-29 (1981). 
a security interest in property of a debtor, but provides minimal help in linking filings to particular collateral.

In most instances, searchers can determine what is actually encumbered only through off-record inquiry. ${ }^{135}$ For example, assume that Secondbank contemplates lending against cooling equipment located in one of the debtor's places of business. The search reveals a prior filing by Firstbank against a "walk-in cooler," but does not give a serial number. To determine whether Firstbank's filing encumbers the contemplated collateral, Secondbank must rely on off-record information from the debtor, Firstbank, or some other source.

Interestingly, while article 9 contemplates that the searcher must make this off-record inquiry, it does not require the parties in possession of the information to respond to a searcher's request. Instead, UCC section 9-208 requires only that secured parties respond to requests from their own debtors. The comment to that section explains that the debtor can then pass the information along to "prospective lenders and purchasers." The drafters assumed that prospective lenders and purchasers would have sufficient leverage to compel their prospective debtors to make disclosure and that those disclosures would be credible even in the absence of recorded documents. The drafters implicitly assumed that the search capacity of the article 9 filing system existed only for the benefit of prospective lenders and purchasers. ${ }^{136}$ In the comment, they lump all other searchers together in the category of "casual inquirer[s] or competitor[s]" who should know what lies behind the financing statements only if the parties to the transaction choose to make disclosure.

One consequence has been to foreclose uses of the filing system that are clearly legitimate. For example, the system is of limited use to bidders at execution, tax, judicial foreclosure, and, to a lesser extent, UCC foreclosure sales because these bidders have no leverage to compel disclosure of information from debtors or prior security interest holders. ${ }^{137}$ The same is true of unsecured creditors who have the right to levy against property of the debtor but first wish to know if it is encumbered.

But the more troubling consequence is to render nearly every search a two-part process, part of which will be slow and less reliable because it must be conducted off-record. One solution to this problem would be to require that financing statements contain descriptions sufficient to enable the searcher

135. UCC $\$ 9-402$ comment 2 states that "The [financing statement] itself indicates merely that the secured party who has filed may have a security interest in the collateral described. Further inquiry from the parties concerned will be necessary to disclose the complete state of affairs."

136. Professor Baird takes the same position in Notice Filing and the Problem of Ostensible Ownership, $12 \mathrm{~J}$ Legal Studies 53 (cited in note 2).

137. One might suppose that discovery and disclosure of the amounts of prior liens against the collateral is an element of a "commercially reasonable sale." But that does not explain how the foreclosing creditors are to accomplish that discovery. The debtor who takes a strategic approach to the sale may choose not to assist the creditor in discovering the amounts of the prior liens as a means of chilling bidding at the sale and thereby controlling the collateral. 
to determine what is encumbered. 138 In essence, the description requirement for financing statements would be similar to the description requirement currently applicable to security agreements, but with the additional proviso that the descriptions be intelligible to a searcher who does not have access to the private dealings between the parties. The use of serial numbers, brand names and physical locations would be encouraged. The effect would be to make it possible for a searcher armed with only publicly available information to determine whether particular property is encumbered.

\section{Liens Other Than Security Interests}

Under the official text of the UCC, only holders of article 9 security interests are required or permitted to file financing statements. But few searchers want to know about only article 9 security interests; most want to discover any type of lien that might have priority over the contemplated filing. To discover them, the searcher must view the collateral itself, search in other filing systems, and make several kinds of off-record inquiries. For example, tax liens may be filed or recorded in county filing systems. Execution liens may be discoverable only from the records of the officer who made the levy. Some statutory liens, such as the liens of repairpersons, may be apparent upon examination of the collateral. But other statutory liens, such as those of landlords or agricultural producers, may not be discoverable through even the most extensive search or careful observation. Some kinds of article 9 security interests are perfected without filing or possession; they may be discoverable only through extensive off-record investigation. To facilitate the searcher's task, once an effective system for filing and searching was in place, it probably would be desirable to expand the categories of liens for which filing was required.

To the extent that other public lien records are computerized, they can easily be linked to the article 9 filing system and made available through a single search. ${ }^{139}$ Alternatively, article 9 could be amended to permit or require the filing of judgments or other types of liens in the article 9 filing system. ${ }^{140}$ The rationale for linking these systems is the same as that for linking article 9 filing systems to each other. It is more efficient for a computer to search all the records than for lawyers to determine in each instance which records should be searched.

138. These descriptions would not be sufficiently specific to serve as search criteria. In that sense, this proposal differs from the proposal for searchable descriptions set forth above.

139. The linking of computerized systems is discussed in the text accompanying notes 67-72.

140. This approach has already been adopted in some states. See for example, Cal Civ Pro Code $\$ \$ 697.510$ (a) (judgment lien created by filing with Secretary of State) and 697.570 (judgments indexed in same manner as financing statements); Cal Comm Code $\$ 9409$ (a) (UCC search reports include judgment liens). See also Alces Survey, question 11 on questionnaire (cited in note 4). 


\section{Conclusion}

The article 9 filing system is in disarray. In theory, it is a system for communicating the existence of security interests from filer to searcher, and its provisions allocate between filer and searcher the burden of effecting that communication. But through misdesign and malfunction, the system has failed to provide an effective infrastructure for that communication. Both filers and searchers take advantage of what is useful in the system, but neither relies on it nor attempts to comply with it fully. As a result, the communication often fails to occur, and the rules instead serve merely to allocate losses between innocent creditors who failed to do the impractical.

Many of the system's problems are amenable to technological solutions. Computerization of the filing system could enable it to operate in fact as it does in theory.

But with computerization will come the realization that the article 9 filing system is not a system, but only a fragment of one. Like improvements in a cross country highway that ends before it reaches the city, improvements in the filing and search capacities of the system will generate pressure for completion. In the case of article 9 filing, that means creation of a fully electronic system in which a search can determine whether particular personal property is encumbered by liens. Automation of the portion of the search system that is currently on record will highlight the labor intensive, off-record portions that remain untouched. The need for some additional types of data will be apparent. But to determine the extent of what should be added, the designers of the system will need to revisit the issues of purpose. They will need to decide what precisely this system is supposed to do. 
